\title{
Effect of Green Fertilizer of Gamal Plant (Gliricidia sepium (Jacq) DC.) On the Growth of Duku (Lansium domesticum Corr.)
}

\author{
Eryani, Fenti, Muswita, M.Si, Upik Yelianti
}

Education of Mathematics and Natural Sciences, Faculty of Teacher Training and Sciences, Universitas Jambi, Jambi, Indonesia.

\begin{abstract}
Duku is one of the fruits favored by the people of Indonesia. Jambi Province produces duku kumpeh (Lansium domesticum Corr.) Which is known as a national superior product. One obstacle in the development of duku kumpeh by farmers in Jambi is the conventional pattern of cultivation, so product availability is not continuous, because farmers only look after old gardens. One of the efforts to increase and accelerate the growth of duku is by giving green fertilizer. One type of green fertilizer is green fertilizer derived from Gamal plants (Gliricidia sepium (Jacq) Dc.). Gamal contains nutrients, namely: 3.7\% nitrogen, $0.2 \%$ phosphorus, $2.2 \%$ potassium, $3.2 \%$ calcium, and $0.8 \%$ magnesium. The purpose of this study was to determine the effect of applying gamal green fertilizer on the growth of duku kumpeh. The study used a Completely Randomized Design (CRD) with 5 levels of fertilizer treatment namely $0 \mathrm{~g}, 6.5 \mathrm{~g}, 13 \mathrm{~g}, 26 \mathrm{~g}$, and $52 \mathrm{~g}$. Each treatment was repeated 5 times. The parameters observed were height increase, number of leaves, leaf area, wet weight, and dry weight of plants. The data obtained were analyzed through Analysis of Variance (Anova), and post hoc Duncan Multiple Range Test (DNMRT) at 5\% significance level. The results showed that the dose of gamal green green fertilizer affected the growth of plant height, but did not affect the number of leaves, leaf area, wet weight and dry weight of the plant.
\end{abstract}

Keyword: Green manure, gamal, duku

Received 7 November 2019 | Revised 28 December2019| Accepted 29 January2020

\section{Introduction}

Duku (L. domesticum Corr.) Belongs to the Meliaceae family. Duku comes from the western region of East Asia, from Thailand to Kalimantan. Duku fruit has thick fruit skin and sweet flesh. Duku fruit skin contains oleoresin and can be used as a medicine for diarrhea or indigestion, in addition to crushing duku seeds are also used to prevent fever. One of the dukuproducing regions in Indonesia is Jambi province. The famous duku in Jambi is duku kumpeh. Duku kumpeh has considerable development potential in the future, considering the duku

\footnotetext{
*Corresponding author at: Mendalo Darat, Jambi Luar Kota, Mendalo Darat, Kec. Jambi Luar Kota, Kabupaten Muaro Jambi, Jambi 36657, Indonesia

E-mail address: muswita_2009@yahoo.co.id
} 
market for Jambi Province itself is still wide open and the name duku kumpeh is already well known outside the Jambi area [1].

The development of duku kumpeh continues to have endeavored since 2010 efforts have been made to develop this by spreading new duku seeds in the Muaro Jambi and Batanghari areas. Efforts to develop seedlings still face obstacles such as community cultivation patterns that still plant duku in their yards and gardens, so that maintenance continuity is still lacking and farmers tend to only look after old plantations rather than supervise and maintain new plantings. This has caused duku production in Jambi Province to tend to be unstable and even decline every year [1].

One effort to improve the quality and accelerate the growth of duku is by applying green fertilizer. Green fertilizer is a fertilizer that comes from plants or parts of plants that are still fresh, then buried in the soil. Green fertilizer is useful for increasing soil organic matter and nutrients, especially nitrogen [2]. Generally, all types of plants can be used as green fertilizer, however, the type of plant that is best for green fertilizer is a type of plant whose roots are symbiotic with nitrogen-binding microorganisms such as beans. Green fertilizer derived from beans has the advantage of supporting the growth of microorganisms that benefit plants, enriching organic matter, restoring leached nutrients, reducing the risk of erosion, and suppressing the growth of weeds [3].

One of the plants that can be utilized is Gamal (Gliricidia sepium (Jacq) Dc). According to Mansur [4], Gamal is a plant species that has many benefits, its leaves can be used as compost, animal feed, firewood, and erosion buffer. Gamal can also fertilize the soil because of its symbiosis with rhizobium bacteria, forming root nodules that can bind nitrogen from the air. According to Agus and Widianto [5] the nutrient content of Gamal (Gliricidia sepium) green fertilizers are: $\mathrm{N} 3.7 \%, \mathrm{P} 0.2 \%, \mathrm{~K} 2.2 \%$, Ca $3.2 \%$, and $\mathrm{Mg} 0.8 \%$.

\section{Materials and Methods}

\subsection{Research Design}

The research design used was a completely randomized design (CRD) with 5 treatments and 5 replications. The treatment is: G0: Podzolic soil + Sand (2: 1); G1: Podzolic soil + Sand (2: 1) + Green gamal 6.5 g / plant; G2: Podzolic soil + Sand (2: 1) + Green gamal 13 g / plant; G3: Podzolic soil + Sand (2: 1) + Green gamal 26 g / plant; G4: Podzolic soil + Sand (2: 1) + Green gamal $52 \mathrm{~g} /$ plant.

\subsection{Research procedure}


The procedure of this research includes several stages, namely the preparation of the research site, the preparation of planting media, the supply of seeds, planting the seeds and maintaining the seeds.

a) Research Site Preparation

The study site was chosen as a flat area and received sufficient sunlight. At the top and around the study site was given a $50 \%$ para net shade.

b) Preparation for Planting Media

The planting media used were a mixture of FMD soil (red yellow Podzolik), sand and green gamal fertilizer (G. sepium) in a ratio of 2: 1 . The soil and sand are first cleaned from the dirt and roots of the plant, after which it is sieved and weighed. Then the gamal is finely chopped and weighed according to the measurement. Soil, sand and gamal are homogenized first, then the planting media is put into a polybag and then allowed to stand for 3 weeks.

c) Provision and planting of Duku Seedlings

The seeds used have age of 2 years with several leaves and a homogeneous height. Then duku seedlings are put into polybags according to treatment.

c) Maintenance of Seedlings

Maintenance includes watering and weeding. Watering is done every day or according to plant needs. Furthermore, weeding is done if there are weeds.

\subsection{Observation of Parameters}

The parameter includes, plant height increase $(\mathrm{cm})$ for 15 weeks, number of leaves, leaf area $\left(\mathrm{cm}^{2}\right)$, wet weight and dry weight of plants $(\mathrm{g})$

\subsection{Data Analysis}

Observational data were analyzed statistically using analysis of variance (ANOVA), if there is a treatment effect, then continued with Duncan New Multiple Range Test (DNMRT) at a level = $5 \%$.

\section{Result and Discussion}

\subsection{Plant Height Increase}

Results of the analysis of variance showed that gamal green fertilizere affected the height of the stem trunk (Table 1) 
Table 1. Average height increase of duku stems with several doses of gamal green fertilizer.

\begin{tabular}{ccc}
\hline No & Treatment & Average height increase $(\mathrm{cm})$ \\
\hline 1 & G0 $(0)$ & 1.5 \\
2 & G1 $(6.5 \mathrm{~g})$ & $3.2 \mathrm{ab}$ \\
3 & G2 $(13 \mathrm{~g})$ & $5.4 \mathrm{~b}$ \\
4 & G3(26 g) & $4.9 \mathrm{~b}$ \\
5 & G4(52 g) & $6.2 \mathrm{~b}$ \\
\hline
\end{tabular}

Note: Numbers followed by the same lowercase letters are not significantly different based on the DNMRT test at the 5\% level.

Table 1 shows that the treatment of gamal green fertilizer at a dose of $13 \mathrm{~g}, 26 \mathrm{~g}$, and $52 \mathrm{~g}$ dose was significantly different from the treatment dose of $0 \mathrm{~g}$ (control), but not significantly different from the treatment of gamal green fertilizer at a dose of $6.5 \mathrm{~g}$. The influence of gamal green canto due to the influence of nutrients especially nitrogen contained in gamal can give effect to plant height. This is in line with the opinion of Poerwowidodo [6] which states that nitrogen acts as a fundamental unit in proteins, nucleic acids, chlorophyll, and other organic compounds. Galag et al., [7] added that nitrogen is the main nutrient for the growth of vegetative parts of plants such as leaves, stems, and roots.

\subsection{Increasing Number of Leaves}

The results of the analysis of variance showed that the administration of gamal green green fertilizer doses had no effect on increasing the number of duku leaves. Table 2, shows that the administration of gamal green fertilizer does not affect the increase in the number of duku leaves.

Table 2. Average increase in the number of duku leaves with several doses of gamal green

\begin{tabular}{ccc}
\multicolumn{2}{c}{ fertilizer. } \\
\hline No & Treatment & Average increase in number of leaves (strands) \\
\hline 1 & G0 $(0)$ & 2.2 \\
2 & G1 $(6.5 \mathrm{~g})$ & 4 \\
3 & G2 $(13 \mathrm{~g})$ & 4.8 \\
4 & G3 $(26 \mathrm{~g})$ & 5.8 \\
5 & G4 $(52 \mathrm{~g})$ & 4.6 \\
\hline
\end{tabular}

The average increase in the number of duku leaves ranges from 2.2 to 5.8 strands. The ineffectiveness of gamal green fertilizer is suspected because the content of $\mathrm{N}, \mathrm{P}$ and $\mathrm{K}$ contained in gamal green fertilizer has not been able to stimulate the increase in the number of leaves. Besides, duku plants are annual plants that require a long time to increase the number of leaves. According to Mulyani [8], after the formation of shoots/buds there are several stages of leaf development, namely the beginning (initiation), initial differentiation, leaf axis development, leaf blade origins, and histogenesis of leaf blade tissue. With the existence of several stages of leaf development, the time needed to increase the number of leaves is relatively long. 


\subsection{Leaf area}

The results of the analysis of variance showed that the administration of gamal green manure dose did not affect the area of duku leaves. The average leaf area at various doses of gamal green green fertilizer ranges from 50.44-69.5 cm (Table 3).

Table 3. Average area of duku leaves with several doses of gamal green fertilizer.

\begin{tabular}{ccc}
\hline No & Treatment & Average leaf area $\left(\mathrm{cm}^{2}\right)$ \\
\hline 1 & G0 $(0)$ & 59.97 \\
2 & G1 $(6.5 \mathrm{~g})$ & 68.63 \\
3 & G2 $(13 \mathrm{~g})$ & 56.36 \\
4 & G3 $(26 \mathrm{~g})$ & 50.44 \\
5 & G4 $(52 \mathrm{~g})$ & 69.50 \\
\hline
\end{tabular}

Table 3.3, shows that the application of gamal green fertilizer does not affect the area of duku seedling leaves. It is suspected that duku has a thick leaf structure so that absorption of light is inhibited, resulting in its development for quite a long time. Leaf area in a plant is closely related to photosynthesis, where the broader the leaf, the more light is absorbed, which will later play an important role in plant survival, helping the plant's metabolic processes and its ability to survive. This is in line with the opinion of Jedeng [9] that the increasing leaf area index increases the capture and reception of more sunlight for photosynthesis so that the assimilate production is high. So the wider the leaves the plant has, the more optimal the process of photosynthesis that occurs in these plants.

\subsection{Plant wet weight}

The results of the analysis of variance showed that the administration of gamal green fertilizer dose did not affect the wet weight of the duku seedlings. Duku wet weight ranges from 18.62 to $27.15 \mathrm{~g}$. The average wet weight duku is presented in Table 4.

Table 4. Average wet weight of duku with several doses of gamal green fertilizer.

\begin{tabular}{ccc}
\hline No & Treatment & Average wet weight $(\mathrm{g})$ \\
\hline 1 & G0 $(0)$ & 18.62 \\
2 & G1 $(6.5 \mathrm{~g})$ & 27.15 \\
3 & G2 $(13 \mathrm{~g})$ & 24.33 \\
4 & G3(26 g) & 22.13 \\
5 & G4 $(52 \mathrm{~g})$ & 24.92 \\
\hline
\end{tabular}

Table 3.4, shows that the application of gamal green green fertilizer does not affect the wet weight gain of duku seedlings. It is suspected that the nutrients contained in the gamal green fertilizer have not been able to increase the water content of plants. This is supported by the opinion of Mulyani [8] that in the woody stems under the epidermis there is a layer of parenchyma cells which then becomes several layers of collenchyma. The rest of the cortex consists of parenchyma cells containing chlorophyll. Pith consists of parenchyma cells containing sap (sap cells) which are also present in the cortex, thus inhibiting the absorption of 
water into the plant body. The wet weight of plants is closely related to the water contained in plants, where most of the components in the plant's body are water, as expressed by Fitter and Hay that water is the main component in green plants, which is $70-90 \%$ of fresh weight. The ability to hold water in plants can help and improve the process of plant growth to be more optimal so that the wet weight of the plant will increase. In this case, water plays an important role in plants that function as solvents and helps biological activities that occur in the body of plants.

\subsection{Plant dry weight}

The results of the analysis of variance showed that the administration of gamal green fertilizer did not influence the dry weight of duku kumpeh seedlings. The average dry weight of duku kumpeh ranges between 6.32-11.71 g. The average dry weight duku is presented in Table 5.

Table 5. Average dry weight of duku with several doses of gamal green fertilizer

\begin{tabular}{ccc}
\hline No & Treatment & Average dry weight $(\mathrm{g})$ \\
\hline 1 & G0 $(0)$ & 6.32 \\
2 & G1 $(6.5 \mathrm{~g})$ & 7.58 \\
3 & G2 $(13 \mathrm{~g})$ & 7.48 \\
4 & G3 $(26 \mathrm{~g})$ & 6.92 \\
5 & G4 $(52 \mathrm{~g})$ & 11.71 \\
\hline
\end{tabular}

Based on Table 5, it is known that the administration of gamal green fertilizer does not affect the dry weight of the duku. It is suspected that the supply of nutrients derived from green gamal fertilizer has not been able to optimize the growth of duku kumpeh seedlings. Plant dry weight according to Sitompul and Guritno [10] is all plant material which is roughly derived from the results of photosynthesis so that it plays an important role in the process of growth in a plant. Green fertilizer based on the content contained therein should have been able to give effect to plant metabolism because there are sufficient nutrients for plants, as stated by Susetya (2014) that the nutrients contained in green fertilizers are N, P, K, and the other elements. Each of these nutrients has an important role in the body of a plant. However, gamal green fertilizer is still unable to influence the dry weight of plants.

According to Lakitan [11] in plant tissue nitrogen is a constituent component of many essential compounds for plants, for example, amino acids. In addition, nitrogen is also a constituent of proteins and enzymes, and nitrogen is also contained in chlorophyll. The second nutrient is phosphorus which is an essential part of various phosphate sugars that play a role in reactions in the dark phase of photosynthesis, respiration and various other metabolic processes. Also, there is potassium which acts as an activator of various enzymes that are essential in photosynthesis and respiration reactions. Concerning the regulation of cell turgor, an important role is to open 
and close the stomata. The process of producing photosynthates is beneficial for all plant organs, thus forming plant organs with optimal growth. Photosynthesis is the result of photosynthesis which is usually in the form of simple sugars that will be translocated to the roots and then to other plant organs.

Furthermore, according to Sitompul and Guritno [10], greater photosynthate production allows the forming of all larger plant organs such as leaves and roots which then produce increasingly greater dry matter production. So that the dry weight of the plant is closely related to the leaves, especially the leaf area, but the leaf area is also not yet optimal in its growth so it also affects the dry weight of the plant which is all the growth processes that occur in the plant body. Dry weight can represent the results of plant metabolites because the leaves and other organs contain the results of metabolites. Dry weight increase is used as an indicator of plant growth because dry weight reflects the accumulation of organic compounds that plants have successfully synthesized from inorganic compounds namely water and $\mathrm{CO}_{2}$.

\section{Conclusion}

Based on the results obtained in this study, it can be concluded that the distribution of gamal ( $G$. sepium) fertilizer influences the increase in duku height, but does not affect the number of leaves, leaf area, fresh weight and plant dry weight.

\section{REFERENCES}

[1] Dinas Pertanian Tanaman Pangan dan Hortikultura Provinsi Jambi. Laporan tahunan dinas pertanian tanaman pangan provinsi Jambi 2010-2014 Dinas pertanian tanaman pangan Provinsi Jambi. 2015

[2] Hadisuwito, S., Membuat Pupuk Organik Cair. Jakarta : PT AgroMedi Pustaka. 2012.

[3] Parnata,A.S., Meningkatkan hasil panen dengan pupuk organik. Jakarta: AgroMedia Pustaka. 2010.

[4] Mansur, I., Teknik Silvikuktur untuk reklamasi lahan bekas tambang. Bogor : SEAMEO BIOTROP. 2011.

[5] Agus,F dan Widianto., Petunjuk praktis konservasi tanah pertanian lahan kering. Bogor : Indonesia World Agroforestry Centre (ICRAF). 2004.

[6] Poerwowidodo, Telaah kesuburan tanah. Bandung : Penerbit Angkasa. 1992.

[7] Galag SL, Aiyen, Muhammad Anshar Pasigai. Growth And Yield Of Onion (Allium Ascalonicum L.) Against Various Concentrations of Liquid Organic Fertilizer. Agroland : The Agriculture Science Journal, 4 (1) 26 - 34. 2017.

[8] Mulyani, S.,ES., Anatomi tumbuhan. Yogyakarta : Kanisius (Anggota IKAPI). 2006.

[9] Jedeng, I.W. Pengaruh jenis dan dosis pupuk organik terhadap pertumbuhan dan hasil ubi jalar (Ipomoea batatas L. Lamb.) varian lokal ungu., Thesis Universitas Udayana : Denpasar. 2011.

[10] Sitompul, M. dan Guritno, B. Analisis Pertumbuhan Tanaman. Yogyakarta : Gajah Mada University Press. 1995.

[11] Lakitan,B., Dasar-dasar fisiologi tumbuhan. Jakarta : PT. Raja Grafindo Persada. 1995. 